\title{
Szívrajzok, mint a funkcionális kapacitás és a koronária-intervenciók óta eltelt idő mutatói
}

\author{
Nagy Alexandra', Szabados Eszter², Tiringer István³, Csathó Árpád ${ }^{3}$
}

\author{
1'Állami Szívkórház, Balatonfüred \\ ${ }^{2}$ PTE KK, I.sz. Belgyógyászati Klinika, Kardiológiai Prevenciós és Rehabilitációs Tanszék, Pécs \\ ${ }^{3}$ PTE ÁOK, Magatartástudományi Intézet, Pécs
}

Levelezési cím:

Dr. Nagy Alexandra PhD

Állami Szívkórház, 8230, Balatonfüred, Gyógy tér 2. E-mail: szandra.nagy@bilx.hu

\begin{abstract}
A szívbetegek betegségreprezentációi és pszichés státusza korábbi vizsgálatok alapján összefüggést mutat a betegek által készített szívrajzok méretével és a szívrajzon ábrázolt sérülések mennyiségével. Jelen tanulmány fő célja a szívkoszorúér-betegek szívrajzainak elemzése, illetve annak a kérdésnek a vizsgálata volt, hogy a rajzváltozók milyen öszszefüggést mutatnak a fizikai funkcionálással, a fáradtság egyes aspektusaival és a szívkoszorúér-betegek funkcionális kapacitásával (MET). Továbbá azt is vizsgáltuk, hogy a szívrajzok mutatnak-e összefüggést a betegségtörténetben megjelenő eseményekkel, mint a miokardiális infarktus és a sebészi beavatkozások (pl. CABG).

Módszerek: A vizsgálatban 120 koronáriabeteg vett részt, akik egy terheléses EKG-vizsgálat mellett kitöltöttek egy pszichológiai kérdőívcsomagot a depresszió, szorongás, fizikai limitációk, vitális kimerültség és fáradtság mérésére és egy szívrajzolásos feladatot.

Eredmények: Az adatok elemzését követően a szívrajzok területe bejósolta a betegek fizikai funkcionálását és funkcionális kapacitását: a nagyobb szívterület alacsonyabb fizikai funkcionálással és funkcionális kapacitással járt együtt. Az időváltozók elemzése során a szívrajzok területe szoros összefüggést mutatott a koszorúér-áthidalás óta eltelt idővel.

Megbeszélés: Vizsgálatunkban a koronáriabetegek által készített szívrajzok a fizikai aktivitások során felhasznált energiabefektetéssel és a műtéti beavatkozások óta eltelt idővel mutatták a legszorosabb összefüggéseket. A rajzok tartalma hasznos módja lehet a páciens tudásának felmérésére szive állapotáról, az esetleges téves hiedelmek tisztázása révén a páciens pszichés distressze csökkenthető, életminősége javulhat, és pozitív irányban változhat adherenciája és terápiás együttmüködése is.
\end{abstract}

Kulcsszavak: betegségreprezentáció, szívrajz, funkcionális kapacitás, kardiovaszkuláris betegségek, multidimenzionális fáradtság

\begin{abstract}
Cardiac Patients' Heart Drawings Reflect Exercise Capacity and the Time Elapsed since Coronary Intervention Procedures

Introduction: Cardiac patients' illness perception and psychological status have been shown to be associated with the size of the heart drawings as well as the amount of heart damage drawn by the patients. The objective of this study was to examine how patients' heart drawings are associated with physical functionality, various aspects of fatigue and exercise capacity. In addition, it was also investigated whether heart drawings show associations with the time elapsed since coronary intervention procedures (e.g. CABG).

Methods: Patients $(\mathrm{N}=120)$ underwent an exercise stress test, performed a heart drawing task and completed questionnaires of depression, anxiety, physical limitations, vital exhaustion and fatigue. Covariate controlled analyses were performed to analyse the associations of heart drawings with exercise capacity, the questionnaire and the time variable data.

Results: The analyses revealed that the heart area drawn by the patients predicts physical functionality and exercise capacity: the larger the heart area, the lower the physical functionality and exercise capacity of the patients. Of the time variables, the strongest association was found between the size of the heart area and the time elapsed since bypass grafting. Conclusion: The conclusion of the study is that patients' heart drawings are related to the energy cost of their physical activities and the time elapsed since surgical interventions with positive outcomes on quality of life. To analyse the content of these drawings might be a simple tool to get information about the patient's perceptions of his illness. With correcting these misperceptions the psychological distress and quality of life can be changed positively, as well as the adherence and compliance of the patient.
\end{abstract}

Keywords: illness representations, heart drawings, functional capacity, coronary heart disease, multidimensional fatigue 


\section{Bevezetés}

Ismert, hogy az objektív klinikai mutatók mellett a kardiovaszkuláris betegek betegségreprezentációja fontos prediktora a betegség prognózisának, valamint jelentősen befolyásolják a betegséggel való megküzdést, és a páciens kezelése során mutatott együttmüködését (1). A betegségreprezentációk mérésének egyik módja a projektív tesztek alkalmazása (2). A rajzos feladatok során például a szívbetegektöl olyan saját készítésü szívrajzokat kérnek, amelyek a szívük jelenlegi állapotát ábrázolják. Broadbent és munkatársai (2004) azt találták, hogy azok a szívinfarktuson átesett betegek, akik sérülést ábrázoltak szívrajzaikon úgy gondolták, hogy betegségük hosszabb ideig fog tartani, és alacsonyabb gyógyulási arányt mutattak szemben azokkal, akik nem ábrázoltak sérülést. Fontos továbbá, hogy a szívrajzok jobban bejósolták a munkába való visszatérést, mint a betegség súlyosságát jelző klinikai markerek, például a Troponin-T-szint (3). A betegek szívrajzai és a gyógyulási mintázat közötti összefüggéseket egy követéses vizsgálat is igazolta (4). Eredményeik alapján a gyógyulás során mutatott szívrajzbeli változások (pl. a szív területének növekedése) reflektálhatnak arra, hogy a beteg milyen mértékben vesz részt például a mérsékelten megeröltető fizikai aktivitásokban. Szívelégtelen betegeknél is összefüggést találtak a nagyobb szívrajzok, több ábrázolt sérülés és negatív betegségreprezentációk, valamint alacsonyabb fizikai funkcionális státusz között (5). Jelen vizsgálatunkban három olyan szemponttal szeretnénk kiegészíteni a rajzvizsgálatokat, amelyekről a korábbi kutatásokban nem esett szó. Először, megvizsgáltuk, hogy a koszorúérbetegek szívrajzai milyen összefüggést mutatnak a szubjektív fizikai funkcionálással és fáradtsággal. A fizikai funkcionálás és fáradtság a negatív kardiovaszkuláris események prediktorai, és jelentősen befolyásolják a betegek életminőségét. Továbbá a betegek betegségreprezentációi kapcsolatban állnak fáradtságukkal is (6). Ezért valószínűsíthetö, hogy a szívrajzok reflektálnak a betegek fizikai funkcionálására és fáradtságára. A korábbi vizsgálatok alapján továbbra sem lehet eldönteni, hogy a szívrajzok az észlelt egészségi állapot fizikai vagy nem fizikai (pl. szociális vagy kognitív) jellegével hozhatók összefüggésbe. Ezért vizsgálatunkban összehasonlítottuk a szívrajzok mutatóinak prediktivitását a fáradtság egyes dimenzióira. A szívelégtelen betegek fizikai funkcionálása egyértelműen kapcsolódott a szívrajzokhoz (5), így feltételeztük, hogy a koszorúér-betegek szívrajzai erősebb prediktivitást mutatnak a fizikai fáradtságra és fizikai funkcionálásra, mint a betegek szociális és kognitív működésére.

Másodszor, több vizsgálat is igazolta, hogy a funkcionális kapacitás (MET) a fatális és non-fatális kardiovaszkuláris események prediktora, és a betegség prognózisának megbízható mutatója (7). Korábbi kutatásokban azt is megfigyelték, hogy a funkcionális kapacitás a betegségreprezentációkkal is kapcsolatot mutat, amely alapján előfordulhat, hogy a MET összefüggésben áll a betegek által készített szívrajzokkal (8). Pontosabban azt feltételeztük, hogy az alacsonyabb funkcionális kapacitást mutató betegek nagyobb méretủ szíveket rajzolnak.

Harmadszor, ugyancsak megnéztük, hogy a szívrajzok mutatnak-e összefüggést a betegségtörténetben megjelenő jelentős események óta eltelt idővel, amilyen a betegség diagnózisa óta eltelt idő, a miokardiális infarktus óta eltelt idő, valamint a koronária-intervenciók óta eltelt idő ( $\mathrm{PCl}$-angioplasztika, CABG-koszorúér-áthidalás). Több vizsgálat is igazolja, hogy a CABG és $\mathrm{PCl}$ akár nyolc évvel a beavatkozást követően is javítja a betegek pszichés jóllétét és fizikai funkcionálását (9). Ezért feltételeztük, hogy a szívrajzok kapcsolatban állhatnak az intervenciós beavatkozások óta eltelt idővel.

\section{Módszerek}

\section{Vizsgálati személyek}

A vizsgálatban 120 koronáriabeteg vett részt (69 férfi, 51 nő; életkor: $M=63,85$; $S D=6,73)$, akiket egy kéthónapos időintervallumon belül válogattunk be a Pécsi Tudományegyetem I. sz. Belgyógyászati Klinikájának ambuláns szakrendelései során. Valamennyi beteg III. fázisú kardiológiai rehabilitáción vett részt.

A betegek akkor vehettek részt a vizsgálatban, ha koszorúér-betegségük mellett nem volt egyéb akut betegségük a vizsgálat ideje alatt, valamint olyan fizikai limitáció sem, amely akadályozta volna a járószalagos terheléses vizsgálat kivitelezését, illetve a vizsgálatot megelőző három hónapban nem történt változás a gyógyszerelésükben. A vizsgálati protokollt a Pécsi Tudományegyetem Regionális Etikai Bizottsága elfogadta (száma: 4826) (1. táblázat).

\section{Vizsgálat során alkalmazott mérőeszközök Szívrajzolási feladat}

A kérdőív kitöltése előtt a betegek betegségreprezentációját egy rajzolási feladat segítségével mértük fel, amelyet a Broadbent és munkatársai (2006) által használt módszerből adaptáltunk. A páciensek egy A4-es lapot kaptak, amelyen egy $9,5 \mathrm{~cm}$ széles és $12 \mathrm{~cm}$ hoszszú keretet helyeztünk el, amely megegyezett a Broadbent és munkatársai (2006) által használt méretekkel (4). A betegeket arra kértük, hogy a rendelkezésükre álló keretbe képzeljék el, majd rajzolják le szívüket a jelenlegi állapotában. Valamennyi résztvevő a következő instrukciót kapta: „Kérjük, rajzoljon egy képet arról, hogy hogyan nézhet ki a szíve! Arra vagyunk kíváncsiak, hogy ön mit gondol arról, hogy nézhet ki a szíve, nem rajzolási képességére."

\section{Kérdőívek}

A Rövidített 9-itemes Beck Depresszió Skála (BDI-9) a depressziós tünetek gyakoriságának felmérésére szol- 
1. TÁBLÁZAT. A betegek szociodemográfiai és komorbid jellemzői és gyógyszerelése

\begin{tabular}{|l|l|}
\hline Változók & Betegek \\
\hline N & 120 \\
\hline Férfi & 69 \\
\hline Nő & 51 \\
\hline Életkor & $\mathrm{M}=63,85 ; \mathrm{SD}=6,73$ \\
\hline Iskolázottság, $n$ (\%) & \\
\hline 8 általános & $10(8,3 \%)$ \\
\hline középiskola & $61(50,9 \%)$ \\
\hline föiskola/egyetem & $49(40,8 \%)$ \\
\hline Testtömegindex (kg/m²) & $\mathrm{M}=29,41 ; \mathrm{SD}=4,83$ \\
\hline Ejekciós frakció (EF) & $\mathrm{M}=58,32 ; \mathrm{SD}=8,93$ \\
\hline Miokardiális infarktus (AMI) & $58(49,2 \%)$ \\
\hline Intervenciók, $n$ (\%) & \\
\hline Szívkoszorúér-áthidalás (CAB) & $60(50 \%)$ \\
\hline Perkután koronária-intervenció (PCI) & $74(61,7 \%)$ \\
\hline Gyógyszerelés, $n$ (\%) & \\
\hline ACE-gátló & $91(75,8 \%)$ \\
\hline Béta-blokkoló & $94(78,3 \%)$ \\
\hline Kalciumcsatorna-blokkoló & $23(19,2 \%)$ \\
\hline Trombocita-gátló & $120(100 \%)$ \\
\hline Vérzsírcsökkentő & $116(96,7 \%)$ \\
\hline Komorbiditás, $n$ (\%) & $23(19,2 \%)$ \\
\hline Diabetes Mellitus & $74(61,7 \%)$ \\
\hline Hipertónia & \\
\hline & \\
\hline
\end{tabular}

gált (10). Az egyes tételek olyan tünetekre kérdeznek rá, mint a pesszimizmus, hangulat, irritabilitás, alvásproblémák, önvád, szomatikus tünetek. Pontozása egy 0-tól 3-ig terjedő skálán történik, így a kapható maximális pontszám 27. A magasabb pontszám a depreszsziós tünetek gyakoriságának emelkedésére utal. Szívbeteg-populációban gyakran használják a páciensek érzelmi-hangulati állapotának mérésére, például szívmútét előtt és után (11). A szubjektív fizikai funkcionálás mérése az SF-36 általános életminőség kérdőív Fizikai funkcionálás alskálájával (FF-10) történt (12). A 10 tételes alskálában a kitöltőknek saját teljesítményüket kell megítélniük egy háromfokú skálán a mindennapi fizikai tevékenységeket, pontosabban az azokkal kapcsolatos korlátozottságot tekintve, mint például öltözködés, bevásárlás, lépcsőzés és séta. Az értékelés egy 0-tól 100-ig terjedő skálán történik. A magasabb érték jobb fizikai státuszt jelez. A kérdőív magyar validálása krónikus veseelégtelen betegek életminőség-vizsgálata során történt meg (13). A The Fatigue Impact Scale (FIS) a fáradtságot multidimenzionális aspektusból ragadja meg, $s$ annak hatását a mindennapi életre három alskála mentén méri fel. 10 tétel foglalkozik a kognitív vagy mentális fáradtsággal, mint a koncentráció, memória, figyelem és gondolkodási zavarok. A fizikai fáradtság alskála ugyancsak 10 tételt tartalmaz, és elsősorban a fizikai aktivitásban megjelenő korlátokra kérdez rá, valamint a fizikai erőbefektetés fenntartásának körülményeire. A szociális funkcionálás mérése 20 tétel segítségével történik, és a szociális izolációra, a társasági tevékenységek korlátozására helyezi a hangsúlyt. A maximálisan elérhető pontszám 160. A magasabb pontértékek egyre súlyosabb fáradtsággal összefüggésben álló korlátozásokat mutatnak (14). A magyar validálás (15) sclerosis multiplexszel élő betegek és egészséges kontrollszemélyek körében történt meg. A Vitális kimerültség (VK) a Rövidített Maastricht Vitális Kimerültség Kérdőív (SMEQ) által került felmérésre (16, 17). A 9 tétel a következőkre kérdez rá: megmagyarázhatatlan fáradtság, elalvási nehézségek, éjszakai felébredés, általános gyengeségérzet, apátia, irritabilitás, energiahiány, demoralizáció, kialvatlanság. A Spielberger Állapot- és Vonásszorongás Kérdőívet (STAI) (18), a szorongás erősségének mérésére alakították ki. A 40 tételből álló Likert-skála első 20 tétele az ún. állapotszorongást méri, tehát a pillanatnyi szorongás értékéről ad információt, míg a következő 20 tétel a vonásszorongásra vonatkozik, vagyis a szorongásra való hajlam mértékét adja meg. Eredetileg a normál felnőtt populáció szorongásának mérésére szánták, de klinikai mintán alkalmazva is megfelelt. A magyar verzió számos mintán megbízható mérőeszköznek bizonyult (19).

A skálák belső konzisztenciája a következő volt: BDI-9 (Cronbach alfa=0,9), PF-10 (Cronbach alfa=0,88), FIS fizikai alskála (Cronbach alfa=0,95), FIS kognitív alskála (Cronbach alfa=0,95), FIS szociális (Cronbach alfa= 0,96), STAI-S (Cronbach alfa=0,94), STAI-T (Cronbach alfa=0,91), VK-teljes (Cronbach alfa=0,86), VK-fáradtság (Cronbach alfa=0,78), VK-alvás (Cronbach alfa= $0,72)$, VK-hangulat (Cronbach alfa $=0,78)$.

\section{Terheléses EKG-vizsgálat}

A terheléses EKG-vizsgálat standard Bruce-protokoll szerint zajlott, amely során végig monitoroztuk a betegek szívfrekvenciáját és vérnyomását. A vizsgálat napján a betegek gyógyszereiket a szokott módon vették be (20). A maximális funkcionális kapacitást a terhelés idejéből, vagyis a járószalagon eltöltött idő hosszából állapítottuk meg, és metabolikus ekvivalensben (MET) fejeztük ki. Valamennyi résztvevő elérte az életkorának megfelelő terhelési szintet, vagyis a számított maximális pulzusszámát.

\section{Adatelemzés}

A szívrajzok elemzése

A páciensek által készített szívrajzokat öt tulajdonság mentén elemeztük:

- a szív hosszúsága,

- szélessége,

- a szív területe,

- valamint a rajzon megjelenő erek és

- sérülések előfordulása. 

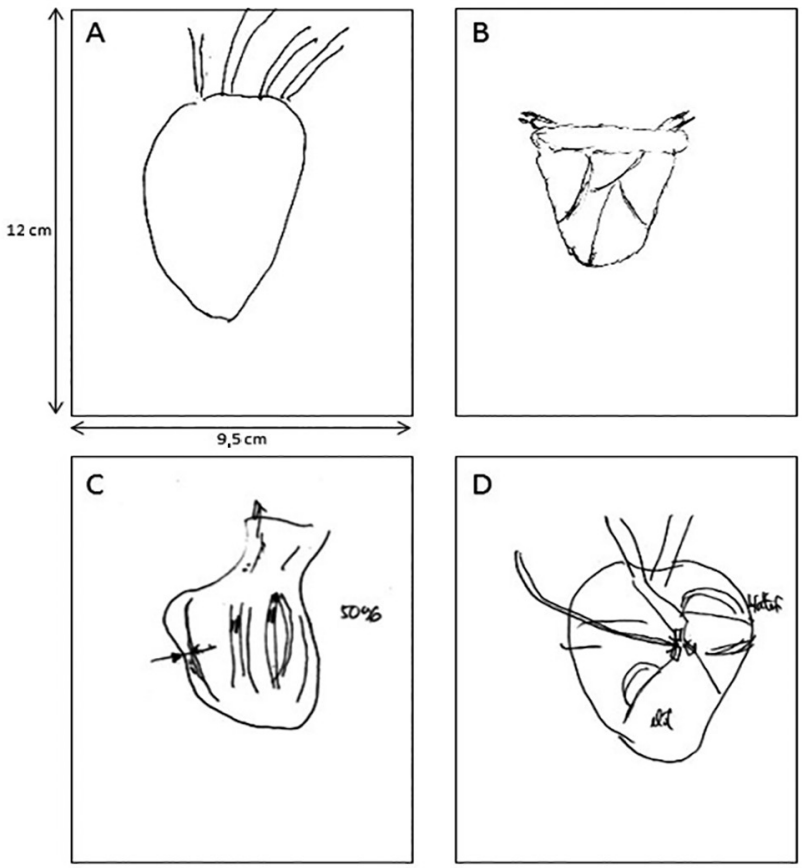

1. ÁBRA. Szívkoszorúér-betegek által készített szívrajzok néhány jellegzetességének bemutatása az egyszerűtől az összetettebb, elzáródott artériákat jelző rajzig (A-D)

Sérülésnek számított a besatírozott, sötét terület a rajzon, az érelzáródás ábrázolása (az érszakaszon megrajzolt blokk, elzáródás) és a mútétre utaló jelek (pl. stent). A rajz hosszúságára vonatkozó adatot a rajzolt szív két vertikális végpontja közötti távolság adta, a rajz szélességére vonatkozó adathoz a rajz horizontális végpontjai közötti távolságot számoltuk ki. A hosszúság, szélesség és a terület kiszámítását Image-J szoftver segítségével végeztük. A terület kiszámítása során, a pontosabb adat érdekében két mérés történt, és a két mérés átlagát használtuk a további elemzések során (1. ábra).

\section{Adatok elemzése}

A Kolmogorov-Smirnov-próba alapján néhány kérdőíves változó eltért a normál eloszlástól, ezért a normalitás javítására négyzetgyök transzformációt végeztünk. A szívrajz változóinak kapcsolatát a MET-tel, a kérdőíves- és időváltozókkal először korreláció-analízissel elemeztük. Ezt követően független mintás t-próbákkal megnéztük, hogy különböznek-e azok a betegek, akik ereket vagy sérüléseket is megjelenítettek rajzaikon azoktól, akiknél ilyen részletek nem jelentek meg. Végül, többváltozós regresszió-analízisek során elemeztük, hogy a szívrajzok milyen mértékben jósolják be a MET-et, valamint a kérdőíves- és időváltozókat, vagyis ezek az értékek lettek a függő változók. Független változóként szerepelt a szívrajzok területe, hossza és szélessége. A kollinearitás elkerülése érdekében, az egyes független változók külön analízisben szerepel- tek. A szívrajz változókon kívül további prediktorként azok kerültek a modellbe, amelyek a rajzváltozókkal vagy valamelyik függő változóval szignifikáns kapcsolatot mutattak, azaz az életkor, BMI, nem, iskolázottság és a komorbid diabetes mellitus.

\section{Eredmények}

A vizsgálatban szereplő kérdőíves és időváltozók, valamint a szívrajzok leíró statisztikáját a 2. táblázat mutatja be. A 3. táblázat pedig a korrelációs koefficienseket és a többváltozós regresszió-analízisek eredményeit mutatja.

A kategóriaváltozók elemzése során nem mutatkozott különbség az ereket és sérüléseket rajzoló, illetve nem rajzoló betegek között. Ezzel szemben a szív területe negatívan korrelált a MET-tel, pontosabban az alacsonyabb MET-értékű betegek nagyobb területű szíveket rajzoltak. A szívterület ugyancsak szignifikáns korrelációt mutatott az FF-10 pontszámmal: azok a betegek, akik nagyobb szívet rajzoltak, nagyobb mértékű korlátozást éltek meg a mindennapi fizikai tevékenységek elvégzése során. Az FF-10-zel szemben a FIS fizikai fáradtsága nem állt szignifikáns kapcsolatban a szív-

2. TÁBLÁZAT. A kérdőíves és időváltozók, valamint a szívrajzok leíró statisztikája

\begin{tabular}{|c|c|c|}
\hline & Átlag (SD) & Tartomány \\
\hline \multicolumn{3}{|l|}{ Szívrajz-változók } \\
\hline Magasság (mm) & $5,26(1,44)$ & $2,1-9,3$ \\
\hline Szélesség (mm) & $4,21(1,32)$ & $2,0-10,2$ \\
\hline Terület (mm) & $71,82(52,71)$ & $6,23-261,43$ \\
\hline \multicolumn{3}{|l|}{ Funkcionális kapacitás } \\
\hline MET & $7,94(2,38)$ & $4,00-13,5$ \\
\hline \multicolumn{3}{|l|}{ Kérdőív-változók } \\
\hline $\begin{array}{l}\text { Fizikai funkcionalitás } \\
\text { (FF-10) }\end{array}$ & $70,38(23,00)$ & $0-100$ \\
\hline \multicolumn{3}{|l|}{ Fáradtság (FIS) } \\
\hline fizikai funkciók & $11,50(9,43)$ & $0-37$ \\
\hline kognitív funkciók & $8,24(8,11)$ & $0-39$ \\
\hline Szociális funkciók & $16,71(15,7)$ & $0-66$ \\
\hline Depresszió (BDI-9) & $3,46(3,44)$ & $0-13$ \\
\hline Vonásszorongás (STAI) & $43,04(10,08)$ & $21-67$ \\
\hline Állapotszorongás (STAI) & $36,35(11,25)$ & $20-70$ \\
\hline $\begin{array}{l}\text { Vitális kimerültség } \\
\text { (SMEQ) }\end{array}$ & $6,55(5,24)$ & $0-18$ \\
\hline \multicolumn{3}{|l|}{ Időváltozók } \\
\hline \multicolumn{3}{|l|}{ Eltelt idő (hónapokban) } \\
\hline diagnózis & $79,65(52,35)$ & $2-265$ \\
\hline miokardiális infarktus & $73,10(48,9)$ & $2-264$ \\
\hline angioplasztika & $63,63(41,22)$ & $2-212$ \\
\hline bypass graft & $64,41(37,28)$ & $11-162$ \\
\hline
\end{tabular}


3. TÁBLÁZAT. A korrelációs koefficiensek és a többváltozós regresszióanalízisek eredményei

\begin{tabular}{|c|c|c|c|}
\hline \multirow[t]{2}{*}{$\mathbf{r}\left(\boldsymbol{B}, \mathbf{R}^{2}\right)$} & \multicolumn{3}{|c|}{ Szívrajz-változók } \\
\hline & Terület & Szélesség & Hosszúság \\
\hline MET & $\begin{array}{c}-0,29^{\star *} \\
\left(-0,23^{\star} ; 0,24\right)\end{array}$ & $\begin{array}{c}0,01 \\
(0,01 ; 0,18)\end{array}$ & $\begin{array}{c}-0,10 \\
(-0,11 ; 0,14)\end{array}$ \\
\hline $\begin{array}{l}\text { Fizikai funk- } \\
\text { cionálás(3) }\end{array}$ & $\begin{array}{c}-0,23^{*} \\
\left(-0,19^{*} ; 0,11\right)\end{array}$ & $\begin{array}{c}0,12 \\
(0,11 ; 0,10)\end{array}$ & $\begin{array}{c}-0,02 \\
(-0,02 ; 0,08)\end{array}$ \\
\hline \multicolumn{4}{|l|}{ Fáradtság } \\
\hline fizikai & $\begin{array}{c}0,12 \\
(0,05 ; 0,09)\end{array}$ & $\begin{array}{c}-0,01 \\
(0,04 ; 0,09)\end{array}$ & $\begin{array}{c}0,02 \\
(0,02 ; 0,09)\end{array}$ \\
\hline kognitív & $\begin{array}{c}0,10 \\
(0,03 ; 0,07)\end{array}$ & $\begin{array}{c}0,01 \\
(0,02 ; 0,07)\end{array}$ & $\begin{array}{c}0,02 \\
(0,04 ; 0,07)\end{array}$ \\
\hline szociális & $\begin{array}{c}0,13 \\
(0,07 ; 0,09)\end{array}$ & $\begin{array}{c}-0,03 \\
(-0,01 ; 0,09)\end{array}$ & $\begin{array}{c}0,02 \\
(0,02 ; 0,09)\end{array}$ \\
\hline Depresszió & $\begin{array}{c}0,13 \\
(0,07 ; 0,07)\end{array}$ & $\begin{array}{c}-0,04 \\
(-0,05 ; 0,07)\end{array}$ & $\begin{array}{c}-0,05 \\
(-0,08 ; 0,07)\end{array}$ \\
\hline \multicolumn{4}{|l|}{ Szorongás } \\
\hline Vonás & $\begin{array}{c}0,12 \\
(0,03 ; 0,16)\end{array}$ & $\begin{array}{c}-0,08 \\
(-0,06 ; 0,16)\end{array}$ & $\begin{array}{c}-0,10 \\
(-0,11 ; 0,17)\end{array}$ \\
\hline Állapot & $\begin{array}{c}-0,03 \\
(-0,06 ; 0,07)\end{array}$ & $\begin{array}{c}-0,20^{*} \\
(-0,17 ; 0,1)\end{array}$ & $\begin{array}{c}-0,23^{*} \\
(0,22 ; 0,11)\end{array}$ \\
\hline $\begin{array}{l}\text { Vitális } \\
\text { kimerültség }\end{array}$ & $\begin{array}{c}0,02 \\
(-0,07 ; 0,13)\end{array}$ & $\begin{array}{c}-0,08 \\
(-0,06 ; 0,13)\end{array}$ & $\begin{array}{c}-0,09 \\
(-0,1 ; 0,14)\end{array}$ \\
\hline \multicolumn{4}{|c|}{ Eltelt idő (hónapok) } \\
\hline diagnózis & $\begin{array}{c}-0,23^{*} \\
(-0,15 ; 0,2)\end{array}$ & $\begin{array}{c}0,04 \\
(0,03 ; 0,18)\end{array}$ & $\begin{array}{c}-0,10 \\
(-0,08 ; 0,18)\end{array}$ \\
\hline $\begin{array}{l}\text { miokardiális } \\
\text { infarktus }\end{array}$ & $\begin{array}{c}-0,32^{*} \\
(-0,25 ; 0,22)\end{array}$ & $\begin{array}{c}-0,01 \\
(-0,07 ; 0,18)\end{array}$ & $\begin{array}{c}-0,17 \\
(-0,20 ; 0,20)\end{array}$ \\
\hline $\begin{array}{l}\text { angio- } \\
\text { plasztika }\end{array}$ & $\begin{array}{c}-0,19 \\
(-0,14 ; 0,07)\end{array}$ & $\begin{array}{c}-0,03 \\
(-0,05 ; 0,07)\end{array}$ & $\begin{array}{c}-0,09 \\
(-0,09 ; 0,07)\end{array}$ \\
\hline $\begin{array}{l}\text { szívkoszorú- } \\
\text { ér- áthidalás }\end{array}$ & $\begin{array}{c}-0,57^{* *} \\
\left(-0,43^{* *} ; 0,40\right)\end{array}$ & $\begin{array}{c}-0,08 \\
(0,02 ; 0,29)\end{array}$ & $\begin{array}{c}-0,11 \\
(0,06 ; 0,30)\end{array}$ \\
\hline
\end{tabular}

Magyarázat: (1) ^p<0,05, " $p<0,01$; (2) A regresszióanalízisek prediktorai: szívrajz, BMI, iskolázottság, életkor, nem, diabetes mellitus; (3) A fizikai funkcionálás (FF-10) adatokkal inverz négyzetgyök-transzformációt végeztünk. Ezért az alacsonyabb pontszámok jobb fizikai státuszt jelölnek.

rajz mutatóival. A nem fizikai jellegü fáradtság dimenziókhoz (szociális és kognitív fáradtság) hasonlóan a vitális kimerültség és a depresszió sem mutatott összefüggést a szívrajzokkal. Egyedül az állapotszorongás korrelált negatívan a szívrajzzal, vagyis a magasabb állapotszorongású személyek szívrajzának hossza és szélessége kisebb volt. Ezek az eredmények azt a feltevésünket igazolják, amely szerint a betegek szívrajzai azok funkcionális kapacitására és fizikai funkcionálására reflektálnak.

A többváltozós regresszió-analízisek ugyancsak megerősítették a szívrajzok, MET és FF-10 szignifikáns kapcsolatát: A szívrajz területe szignifikáns független prediktornak bizonyult mind a MET-re, mind az FF-10re. A szívterület prediktivitása erőteljesebb volt a MET esetében. Amikor a MET volt a függő változó, a modellben szereplő prediktorok a függő változó 23\%-át magyarázták, az FF-10 esetében ez 11\% volt. A korre- láció-analízis során azonban egy erős kapcsolatot találtunk a MET és FF-10 között ( $r=-0,37, p<0,001)$. Mindezek alapján feltételezhetjük, hogy a szívrajzok és FF-10 közti kapcsolatot a MET mediálhatja. A MET lehetséges mediátor szerepét egy mediátor modellel ellenőriztük, ahol a MET-et szintén a regresszió-analízisekben szereplő prediktorok közé soroltuk, míg az FF-10 lett a függő változónk. A MET kontrollálását követően az $F F-10$ és a szívterület közti összefüggés eltűnt $(b=0,13$, $t=1,38$, ns.). A fizikai funkcionálás és szívterület közötti kapcsolat tehát közvetett a MET-en keresztül. Sobel teszttel ugyancsak a MET mediátor szerepe bizonyítható az előbbi két változó esetében $(z=2,00, p<0,05)$ (2. ábra).

Az időváltozók korrelációelemzése alapján a szívrajzok területe csökkent a szívbetegség diagnosztizálása óta eltelt idő növekedésével. A szívrajzok területe ugyancsak reflektált a szívinfarktus óta eltelt időre: Minél kisebb volt a szívrajz területe, annál régebben történt az infarktus. A legerősebb negatív összefüggést azonban a CABG óta eltelt idővel találtunk, és érdekes módon ez az összefüggés a $\mathrm{PCl}-\mathrm{vel}$ nem mutatkozott. Ezt követően további elemzéseket végeztünk ezen összefüggések vizsgálatára. A többváltozós regresszióanalíziseket követően a szívrajz területe szignifikáns összefüggést mutatott az AMI és a szívbetegség diagnosztizálása óta eltelt idővel. A modellben szereplő prediktorok a függő változó varianciájának 17\%-át (AMI, mint függő változó) és 27\%-át (diagnózis óta eltelt idő, mint függő változó) magyarázták. Ezen kívül a szívrajz területe függetlenül bejósolta a CABG óta eltelt időt. A szívrajz prediktív ereje ennél az időváltozónál bizonyult a legerősebbnek, ugyanis a függő változó varianciájának $37 \%$-át magyarázta. A szívrajz és CABG óta eltelt idő összefüggésének elemzésekor a MET-értékeket is a prediktorok közé soroltuk. Ezt azért tartottuk szükségesnek, mert szignifikáns kapcsolatot találtunk a MET és CABG óta eltelt idő között ( $r=0,41$; a többi időváltozóval a MET nem mutatott szignifikáns kapcsolatot). A szívrajz területe a MET-értékek kontrollálását követően is szignifikáns prediktora maradt a CABG óta eltelt idő-

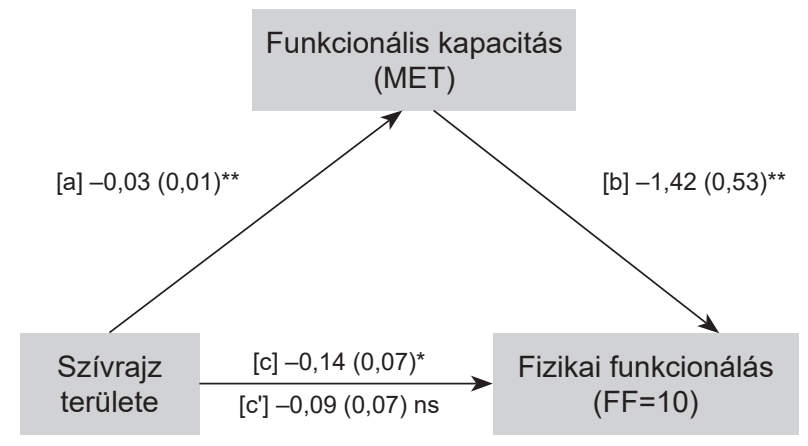

2. ÁBRA. A MET mediátor szerepének bemutatása a szívrajzok területe és a betegek fizikai funkcionálása között 
nek $(b=-0,43, t=-3,06, p<0,01)$. Ez az eredmény azt is mutatja, hogy a MET nem mediálja a szívrajz területe és a CAB óta eltelt idő kapcsolatát. A MET nem szignifikáns mediátor szerepét Sobel-analízissel is alátámasztottuk ( $z=-1,14$, ns.). Ilyen összefüggést a szívrajz területe és $\mathrm{PCl}$ között nem találtunk.

Eredményeink támogatták azon feltevésünket, amely szerint a szívrajzok összefüggésben állhatnak a szívbetegség során megjelenő jelentős eseményekkel, legerősebben a mütéti beavatkozások óta eltelt idővel.

\section{Megbeszélés}

Reynolds és munkatársai (2007) azt találták, hogy azok a szívelégtelen páciensek, akik rosszabb fizikai státuszról számoltak be, hajlamosabbak voltak sérülést megjeleníteni szívrajzaikon (5). Ezzel összhangban, egy másik kérdőívet alkalmazva (FF-10) jelen vizsgálatban azt találtuk, hogy a koszorúérbetegek által rajzolt szív területe növekedést mutatott a fizikai funkcionálás csökkenésével. Érdekes azonban, hogy a fáradtságdimenziók, köztük a fizikai skála (FIS) sem mutatott összefüggést a szívrajzokkal. Míg a FIS általános, szituáció-független állításokat tartalmaz az egyén fáradtságáról, addig az FF-10 konkrét, mindennapi fizikai aktivitásokra kérdez rá, mint a bevásárlás vagy tisztálkodás. Eredményeink tehát arra utalhatnak, hogy a szívrajzok inkább ezekre a specifikus, szituációfüggő tevékenységekre reflektálnak az általános fáradtságszint helyett.

Mindemellett a szívterület a MET független prediktorának bizonyult jelen vizsgálatunkban. Az egyén MET-értéke elöre jelezheti mind a fatális, mind a non-fatális kardiovaszkuláris eseményeket, ezért eredményünk, miszerint a páciensek szívükről alkotott reprezentációja reflektál egy ilyen fontos mutatóra bizonyítja a rajztechnikák alkalmazásának klinikai relevanciáját. Eredményeink a szívrajzok, a MET- és FF-10-értékek kapcsolatáról azt támogatják, hogy a koszorúérbetegek szívük állapotáról alkotott képe a fizikai aktivitás során felhasznált energiamennyiség és észlelt fizikai funkcionálás közti kapcsolatokon alapszik.

Végül, szoros kapcsolat mutatkozott a szívterület és a CABG-mütét óta eltelt idő között. Ilyen összefüggés a szívrajz és PCl között nem jelent meg. A szívrajzok CABG-ra való erősebb prediktivitását a két beavatkozás eltérő hatékonyságával magyarázták korábbi hosszmetszeti vizsgálatokban. Bravata és munkatársai (2007) áttekintő tanulmányában a két intervenció hatékonyságát hasonlították össze. Azt találták, hogy a CABG hatékonyabban csökkentette az anginás tüneteket a PCl-vel szemben. A PCl-t követő gyakoribb anginás tünetek negatívan hathatnak az észlelt egészségi állapotra (21). A CABG több évvel a beavatkozást követően is javítja az egyén fizikai és emocionális állapotát (9), és eredményeink is utalhatnak arra, hogy a szívrajzok érzékeny mutatói lehetnek a CABG utáni hosszabb panaszmentes időszaknak. További vizsgálatok szükségesek azonban ahhoz, hogy a köztes folyamatokat tisztázni lehessen, illetve, hogy a PCl-t követő megfigyelések még manapság, az új típusú stentek használatánál is megállják-e a helyüket.

\section{Következtetések}

Összességében elmondható, hogy vizsgálatunk is indikálja a szívrajzok alkalmazásának fontosságát a kardiológiában. A rajzok tartalma hasznos módja lehet a páciens tudásának felmérésére szíve állapotáról (sérülés mértéke, szívmüködés, intervenciók szükségessége), valamint a félreértések tisztázására, amely által elkerülhetővé válna a pszichés distressz hosszú távú fennmaradása. A pszichés distressz csökkentésével a páciens életminősége javul, és pozitív irányban változhat adherenciája és terápiás együttműködése is (22). Így a rajztechnika nemcsak a pszichiátriai, de a kardiológiai rehabilitáció során megjelenő betegedukáció egy fontos elemévé válhatna.

\section{Támogatás}

Csathó Árpád kutatómunkáját a Nemzeti Kutatási, Fejlesztési és Innovációs Hivatal - NKFIH (K120012) támogatta.

\section{Irodalom}

1. Kaptein AA, Klok T, Moss-Morris R, et al. Illness perceptions: impact on self-management and control in asthma. Current Opinion in Allergy and Clinical Immunology 2010; 10: 194-199. doi: 10.1097/ ACl.0b013e32833950c1.

2. Weinman J, Petrie K, Moss-Morris R, et al. The Illness Perception Questionnaire: A new method for assessing the cognitive representation of illness. Psychology \& Health 1996; 11: 431-435. doi: 10.1080/08870449608400270

3. Broadbent E, Petrie KJ, Ellis CJ, et al. A picture of health- myocardial infarction patients' drawings of their hearts and subsequent disability. Journal of Psychosomatic Research 2004; 57: 583-587. doi: 10.1016/j.jpsychores.2004.03.014

4. Broadbent E, Ellis CJ, Gamble G, et al. Changes is patient drawings of the heart identify slow recovery after myocardial infarction. Psychosomatic Medicine 2006; 68: 910-913. doi: 10.1097/01. psy.0000242121.02571.10

5. Reynolds L, Broadbent E, Ellis CJ, et al. Patients' drawings illustrate psychological and functional status in heart failure. Journal of Psychosomatic Research 2007; 63 (5): 525-532. doi: 10.1016/j. jpsychores.2007.03.007

6. Alsén $P$, Brink E, Persson LO, et al. Illness perceptions after myocardial infarction: Relations to fatigue, emotional distress, and health-related quality of life. Journal of Cardiovascular Nursing 2010; 25(2): E1-E10. doi: 10.1097/JCN.0b013e3181c6dcfd.

7. Bartels MN. Fatigue in cardiopulmonary disease. Physical Medicine and Rehabilitation Clinics of North America 2009; 20: 389-404. doi: 10.1016/j.pmr.2008.12.002

8. Zoeckler N, Kenn K, Kuehl K, et al. Illness perceptions predict exercise capacity and psychological well-being after pulmonary rehabilitation in COPD patients. Journal of Psychosomatic Research 2014; 76 (2): 146-151. doi: 10.1016/j.jpsychores.2013.11.021. 
9. Lukkarinen H, Hentinen M. Treatments of Coronary Artery Disease Improve Quality of Life in the Long Term. Nursing Research 2006; 55 (1): 26-33.

10. Furlanetto LM, Mendlowicz MV, Bueno JR. The validity of the Beck Depression Inventory-Short Form as a screening and diagnostic instrument for moderate and severe depression in medical inpatients. Journal of Affective Disorders 2005; 86: 87-91. doi: 10.1016/j. jad.2004.12.011

11. Tordai Z. Szívbetegek érzelmi-hangulati állapotának jellegzetességei szívmütét előtt és után. Mentálhigiéné és Pszichoszomatika 2005; 6(3): 181-196.

12. Brazier JE, Harper R, Jones NMB, et al. Validating the SF-36 health survey questionnaire: new outcome measure for primary care. British Medical Journal 1992; 305: 160-164.

13. Barótfi Sz. Krónikus vesebetegek életminőségének vizsgálata. Budapest: Doktori értekezés; 2006. p. 24-26.

14. Fisk JD, Ritvo PG, Ross L, Haase DA, Marrie TJ, Schlech WF. Measuring the functional impact of fatigue: initial validation of the fatigue impact scale. Clinical Infectious Diseases 1994; 18: S79-S83. 15. Losonczi E, Bencsik K, Rajda C, et al. Validation of the Fatigue impact scale in Hungarian patients with multiple sclerosis. Quality of Life Research 2011; 20: 301-306. doi: 10.1007/s11136-010-9749-7

16. Appels A, Höppener P, Mulder P. A questionnaire to assess pre- monitory symptoms of myocardial infarction. International Journa of Cardiology 1987; 17: 15-24. doi: 10.1016/0167-5273(87)90029-5 17. Kopp M, Skrabszki Á, Szedmák S. Psychosocial risk factors, inequality and self-rated morbidity in a changing society. Social Science and Medicine 2000; 51: 1351-1361.

18. Bieling PJ, Antony MM, Swinson RP. The State-Trait Anxiety Inventory, Trait version: structure and content re-examined. Beaviour Research and Therapy 1998; 36 (7-8): 777-788.

19. Sipos K, Sipos M. The development and validation of the Hungarian Form of the State-Trait Anxiety Inventory.Series in Clinical \& Community Psychology: Stress \& Anxiety 1983; 2: 27-39.

20. Montalescot G, Sechtem U, Achenbach S, et al. 2013 ESC guidelines on the management of stable coronary artery disease. The Task Force on the management of stable coronary artery disease of the European Society of Cardiology. European Heart Journal 2013; 34: 2949-3003. doi: 10.1093/eurheartj/eht296.

21. Bravata DM, Gienger AL, McDonald KM, et al. Systematic Review: The Comparative Effectiveness of Percutaneous Coronary Interventions and Coronary Artery Bypass Graft Surgery. Annuals of Internal Medicine 2007; 147 (10): 703-716.

22. Cooper A, Lloyd G, Weinman J, et al. Why patients do not attend cardiac rehabilitation: role of intentions and illness beliefs. Heart 1999; 82: 234-236. 